Check for updates

Cite this: RSC Adv., 2018, 8, 38384

Received 5th September 2018 Accepted 29th October 2018

DOI: $10.1039 / c 8 r a 07404 f$

rsc.li/rsc-advances

\section{Kinetic investigation for the catalytic reduction of nitrophenol using ionic liquid stabilized gold nanoparticles $\uparrow$}

\author{
Sachin R. Thawarkar, ${ }^{* a}$ Balu Thombare, ${ }^{b}$ Bhaskar S. Munde \\ and Nageshwar D. Khupse (DD $* d$
}

We demonstrate the synthesis of gold nanoparticles (AuNP) stabilized by 1-butyl-3-hexadecyl imidazolium bromide (Au@ $\left[\mathrm{C}_{4} \mathrm{C}_{16} \mathrm{Im}\right] \mathrm{Br}$ ) and their use as a catalyst for the reduction of nitrophenol. The AuNPs show excellent stability in presence of $\left[\mathrm{C}_{4} \mathrm{C}_{16} \mathrm{Im}\right] \mathrm{Br}$ ionic liquids for the reduction of 4-nitrophenol and 2nitrophenol using $\mathrm{NaBH}_{4}$ as a reducing agent. The detailed kinetics for the reduction of 4-nitrophenol and 2-nitrophenol were investigated and the catalytic activity of $A u @\left[C_{4} C_{16} / \mathrm{m}\right] \mathrm{Br}$ was evaluated. The pseudo first-order rate constant $\left(k_{\text {app }}\right)$ values for 4-nitrophenol was observed to be greater than that of 2-nitrophenol and explained on the basis of hydrogen bonding present in 2-nitrophenol. Au@ [ $\left.\mathrm{C}_{4} \mathrm{C}_{16} \mathrm{Im}\right]$ $\mathrm{Br}$ showed good separability and reusability and hence, it can be used for the complete reduction of nitrophenols in multiple cycles. The Langmuir-Hinshelwood reaction mechanism is elucidated for reduction of 4-nitrophenol by $\mathrm{Au} @\left[\mathrm{C}_{4} \mathrm{C}_{16} \mathrm{Im}\right] \mathrm{Br}$ nanocatalyst on the basis of the $k_{\mathrm{app}}$ values. The thermodynamic activation parameters such as activation energy, enthalpy of activation and entropy of activation were determined and explained using the temperature dependent kinetics for the reduction of nitrophenol using Au@ $\left[C_{4} C_{16} \mid \mathrm{m}\right] \mathrm{Br}$. The above results reveal that the $A u @\left[C_{4} C_{16} \mid \mathrm{m}\right] \mathrm{Br}$ nanocatalyst demonstrates excellent catalytic performance for the reduction of nitrophenol by $\mathrm{NaBH}_{4}$ at room temperature.

\section{Introduction}

Metal nanoparticles of different sizes, shapes, and composition have many important catalytic applications ${ }^{1-4}$ as well as applications in biosensing, ${ }^{5}$ optoelectronics, ${ }^{6}$ petroleum industries, chemical conversion, biology, ${ }^{7}$ etc. Gold nanoparticles (AuNPs) have attracted considerable interest due to their exceptionally high surface-to-volume ratios and abundance of edge and corner atoms. ${ }^{8,9}$ Recently, gold nanoparticles have attracted enormous attention in the field of chemical processes due to their unique stability, selectivity, and catalytic activities for transformation reactions. ${ }^{10}$ The high surface energy of metal NPs makes the surface atoms very active, which leads fast aggregation of the metal NPs. ${ }^{11}$ It is essential to use a capping agent to prevent the aggregation of AuNPs. ${ }^{12,13}$ To synthesize stable metal NPs in

${ }^{a}$ Physical and Materials Chemistry Division, CSIR-National Chemical Laboratory, Dr. Homi Bhabha Road, Pune-411008, India. E-mail: sachinthawarkar@gmail.com ${ }^{b}$ Department of Physics, Savitribai Phule Pune University, Ganeshkhind, Pune 411007, India

${ }^{c}$ Department of Physics, K. K. M. College, Manwath, Parbhani 431505, India

${ }^{d}$ Centre for Materials for Electronics Technology (C-MET), Ministry of Electronics and Information Technology (Meit), Government of India, Panchawati, Off Pashan Road, Pune-411008, India. E-mail: nageshkhupse@gmail.com

$\uparrow$ Electronic supplementary information (ESI) available. See DOI: 10.1039/c8ra07404f solution, the addition of a stabilizing agent is required to prevent aggregation. Thiols have been most commonly used as a stabilizer for AuNPs. However, thiol-stabilized AuNPs are relatively inert. Hence, further replacement of thiols with other ligands may not be easy, thus affecting the labile nature of the AuNPs. Thus, surface bound ligands are used to maintain the nanostructures, but they can block the reactive surface sites, resulting in the reduction of catalytic activity. Therefore, to prepare stable colloidal NPs with sufficient lability, there needs to be a suitable selection of the surface ligand. Furthermore, the effect of capping agents on the catalytic activity of the NPs has been investigated and reported. ${ }^{14}$ An inverse relationship between stability and catalytic activity has been observed. Hence, it is necessary to maintain stability and catalytic activity of the NPs by selecting suitable stabilizing ligands. Ionic liquids are also used as suitable capping agents for the AuNPs. ${ }^{15,16}$ AuNPs stabilized with ionic liquids were synthesized and were observed to show excellent stability. ${ }^{17}$ The interaction of the NPs with ionic liquids is occurs through the imidazolium ring, while the alkyl chain remains away from NP surface. ${ }^{17}$

The reduction of 4-nitrophenol is a very simple reaction for the analysis of reaction kinetics and improvement of catalytic activity. ${ }^{18-21}$ Moreover, this reaction is a well-known model reaction for determining the activity of a catalyst because of the convenience of analyzing the progress of the reaction and the 
absence of by-products. ${ }^{22}$ In general, nitrophenols are not reduced by $\mathrm{NaBH}_{4}$ in aqueous or non-aqueous solutions without a catalyst. The reduction of nitro compounds to the corresponding amines is an important industrial reaction. Amines are the starting compounds for several synthesis processes as intermediates such as azo, imines, and amides and furthermore, these compounds can be converted to other important intermediates that have many applications in agriculture, pharmaceuticals, dyes, polymers and many of them are biologically active. ${ }^{23-25}$ However, the disadvantage of the reaction for nitro compound reduction is the use of high temperatures, long reaction times and most importantly the use of costly catalysts. Therefore, it is necessary to develop a method for the conversion of 4-nitrophenol to 4-aminophenol in aqueous solution under mild conditions by using an appropriate catalyst. An aqueous solution of 4-nitrophenolate ion shows a peak at $\lambda_{\max }=400 \mathrm{~nm}$. The disappearance of this peak to form a new peak at $300 \mathrm{~nm}$ corresponds to the formation of $p$ aminophenol. This reaction has been greatly studied by many groups using noble metal NPs, dendrimers and nanorods as catalysts. ${ }^{26-28}$ Several researchers have reported the reduction of nitrophenol by using AuNPs. Herein, we analyzed the efficiency of $\mathrm{Au} @\left[\mathrm{C}_{4} \mathrm{C}_{16} \mathrm{Im}\right] \mathrm{Br}$ for the catalytic reduction of nitrophenol. It is reported that various nanostructured materials have been used as catalysts for the reduction of nitrophenols under mild reaction conditions. For example, $\mathrm{Au}_{25}$ clusters, gold-palladium nanoalloys, gold nanowires and $\mathrm{Au} @ \mathrm{Fe}_{3} \mathrm{O}_{4}$ yolk-shell nanostructures, have been used as effective catalysts for the reduction of 4-nitrophenol. ${ }^{29-31}$ Many reports indicate that the NPs used for the reduction of 4-nitrophenol follow two mechanisms: (1) Langmuir-Hinshelwood ( $\mathrm{L}-\mathrm{H})$ mechanism and (2) EleyRideal (E-R) mechanism. ${ }^{32-35}$ Several research groups have analyzed the kinetics of the reduction reaction by varying the concentration of 4-nitrophenol and $\mathrm{NaBH}_{4}$ for determining the reaction mechanism. ${ }^{2,35,36}$ It has also been illustrated that the mechanism for the reduction reaction of 4-nitrophenol and $\mathrm{NaBH}_{4}$ involves adsorption of 4-nitrophenol on the surface of the catalyst, and the reaction could proceed through the $\mathrm{L}-\mathrm{H}$ mechanism. However, in the E-R mechanism, only one species is adsorbed on the surface of the catalyst, and the reaction is promoted.

In the present study, we synthesized ionic liquid $\left[\mathrm{C}_{4} \mathrm{C}_{16} \mathrm{Im}\right] \mathrm{Br}$ stabilized AuNPs for the catalytic reduction of 4-nitrophenol and 2-nitrophenol. We also studied the kinetics and catalytic activity of the reduction of nitrophenol using Au@[ $\left.\mathrm{C}_{4} \mathrm{C}_{16} \mathrm{Im}\right] \mathrm{Br}$. The $\mathrm{L}-\mathrm{H}$ mechanism has been explained on the basis of kinetic data and catalytic activity of $\mathrm{Au} @\left[\mathrm{C}_{4} \mathrm{C}_{16} \mathrm{Im}\right] \mathrm{Br}$ for the reduction reaction of 4-nitrophenol. This study also proposes a deep insight into the kinetics of the reduction of nitrophenol from thermodynamic parameters such as activation energy $\left(\Delta E_{\mathrm{a}}\right)$, enthalpy of activation $\left(\Delta H^{\#}\right)$ and entropy of activation $\left(\Delta S^{\#}\right)$.

\section{Experimental section}

\subsection{Kinetic measurements}

An aqueous solution of $1 \times 10^{-4} \mathrm{M}$ of 4-nitrophenol was prepared and then, $20 \mathrm{mg}$ of $\mathrm{Au} @\left[\mathrm{C}_{4} \mathrm{C}_{16} \mathrm{Im}\right] \mathrm{Br}$ catalyst was added to this solution. Finally, an aqueous solution $1 \times 10^{-3} \mathrm{M}$ of $\mathrm{NaBH}_{4}$ was added to above mixture. This reaction was performed in $\mathrm{N}_{2}$ atmosphere. The reaction progress was monitored at $400 \mathrm{~nm}$ in $\mathrm{UV}$, which is the $\lambda_{\max }$ of 4-nitrophenolate ion, by using a UV-vis adsorption spectrophotometer. The absorption peak at $400 \mathrm{~nm}$ decreases with time, indicating the reduction of 4-nitrophenol. The pseudo first-order rate constants $\left(k_{\text {app }}\right)$ were calculated by fitting the first-order rate constant equation for $\ln \left(A_{0} / A_{t}\right)$ values against $t$ (s) with a linear fit, where, $A_{0}$ and $A_{t}$ are the initial absorbance and absorbance after a given time, respectively. The correlation coefficients, i.e., $r$ values for this linear fits, varied from 0.96 to 0.99 . The $k_{\text {app }}$ values were obtained with an accuracy of $\pm 5 \%$. The experimental $k_{\text {app }}$ values are the average values for triplicate experiments. The effect of temperature on the $k_{\text {app }}$ values were studied by varying the temperature from 283.15 to $318.15 \mathrm{~K}$.

\subsection{Transmission electron microscopy (TEM)}

To determine the morphology and size of $\mathrm{Au} @\left[\mathrm{C}_{4} \mathrm{C}_{16} \mathrm{Im}\right] \mathrm{Br}$ present in the aqueous solution, one drop of solution was placed on a carbon-coated $\mathrm{Cu}$ grid and air dried. The image was taken by placing the sample-containing the grid in a TECHNAI G2 20 S-TWIN high-resolution transmission electron microscope operating with a LaB6 filament and at a voltage of $200 \mathrm{kV}$.

\section{Results and discussion}

We synthesized ionic liquid-stabilized AuNPs according to a procedure reported in literature. ${ }^{17}$ For this, an aqueous solution of $\left[\mathrm{C}_{4} \mathrm{C}_{16} \mathrm{Im}\right] \mathrm{Br}$ and a solution of $\mathrm{HAuCl}_{4}$ were mixed in the molar ratio of $10: 1 . \mathrm{NaBH}_{4}$ is added to this mixture dropwise with constant stirring. The color of the solution turned red wine, confirming the formation of AuNPs, as shown in Fig. S1. $\dagger$ Centrifugation was performed immediately after the formation of $\mathrm{Au} @\left[\mathrm{C}_{4} \mathrm{C}_{16} \mathrm{Im}\right] \mathrm{Br}$ to remove impurities and also obtain the AuNPs with an appropriate size distribution. The size of $\mathrm{Au} @\left[\mathrm{C}_{4} \mathrm{C}_{16} \mathrm{Im}\right]$ Br was observed to be about $10 \mathrm{~nm}$, as shown in the TEM image (Fig. 1). The as-prepared solution of $\mathrm{Au} @\left[\mathrm{C}_{4} \mathrm{C}_{16} \mathrm{Im}\right] \mathrm{Br}$ remains stable for more than a month without agglomeration in the aqueous solution. We confirmed the formation of AuNPs capped with $\left[\mathrm{C}_{4} \mathrm{C}_{16} \mathrm{Im}\right] \mathrm{Br}$ with the help of UV-vis spectroscopy. The

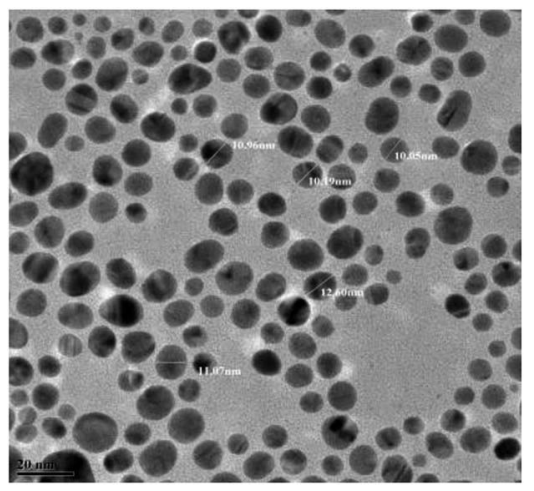

Fig. 1 TEM image of Au@ $\left[C_{4} C_{16} \mathrm{Im}\right] \mathrm{Br}$ nanoparticles in water. 
stability of the AuNPs was due to the higher alkyl chain length of the ionic liquid, which was confirmed by ${ }^{1} \mathrm{H}-\mathrm{NMR}$ and surface enhanced Raman spectroscopy. ${ }^{37}$ Thus, $\mathrm{Au} @\left[\mathrm{C}_{4} \mathrm{C}_{16} \mathrm{Im}\right] \mathrm{Br}$ is stable due to protection of the imidazolium ring via the C-2 proton as well as steric hindrance due to the alkyl chains of the imidazolium ionic liquid. Moreover, a charged layer of ions from the ionic liquids was produced around the AuNPs, which repelled other AuNPs and enhanced the stability of $\mathrm{Au} @\left[\mathrm{C}_{4} \mathrm{C}_{16} \mathrm{Im}\right] \mathrm{Br}$.

\subsection{Catalytic reduction of 4-nitrophenol and 2-nitrophenol using Au@[ $\left.\mathrm{C}_{4} \mathrm{C}_{16} \mathrm{Im}\right] \mathrm{Br}$ catalyst}

The catalytic reduction of 4-nitrophenol and 2-nitrophenol to their corresponding derivatives, 4-aminophenol and 2-aminophenol in the presence of $\mathrm{NaBH}_{4}$ was chosen as the model reaction to investigate the catalytic activity of $\mathrm{Au} @\left[\mathrm{C}_{4} \mathrm{C}_{16} \mathrm{Im}\right] \mathrm{Br}$. Fig. 2 shows the time-dependent UV-vis absorption spectra for the reduction of 4-nitrophenol using the $\mathrm{Au} @\left[\mathrm{C}_{4} \mathrm{C}_{16} \mathrm{Im}\right] \mathrm{Br}$ catalyst. An aqueous solution of 4-nitrophenol shows an absorption peak at $318 \mathrm{~nm}$ in the UV visible region, but on addition of $\mathrm{NaBH}_{4}$, the peak shifts to $400 \mathrm{~nm}$ due to the formation of 4nitrophenolate ions. The peak intensity at $400 \mathrm{~nm}$ immediately starts to decrease with the formation of a new additional peak at $300 \mathrm{~nm}$, which corresponds to the formation of 4-aminophenol. In addition, the yellow color solution of 4-nitrophenol begins to disappear with time and a colourless solution is observed, which indicates the completion of the reaction. We have also performed the reduction of 4-nitrophenol in the absence of $\mathrm{Au} @\left[\mathrm{C}_{4} \mathrm{C}_{16} \mathrm{Im}\right]$ $\mathrm{Br}$. The peak corresponding to the phenolate ion at $400 \mathrm{~nm}$ remained unaffected with time, suggesting that the reduction of 4-nitrophenol does not occur in the absence of a catalyst.

A similar experiment was performed for 2-nitrophenol and similar results as for 4-nitrophenol were observed. Nitrogen was purged before the addition of $\mathrm{NaBH}_{4}$ to remove dissolved oxygen in water, which reacts at a faster rate with borohydride than nitrophenol.

\subsection{Kinetic analysis of nitrophenols}

The calculated rate constant of the reaction is a pseudo firstorder rate constant $\left(k_{\text {app }}\right)$ due to the presence of excess $\mathrm{NaBH}_{4}$

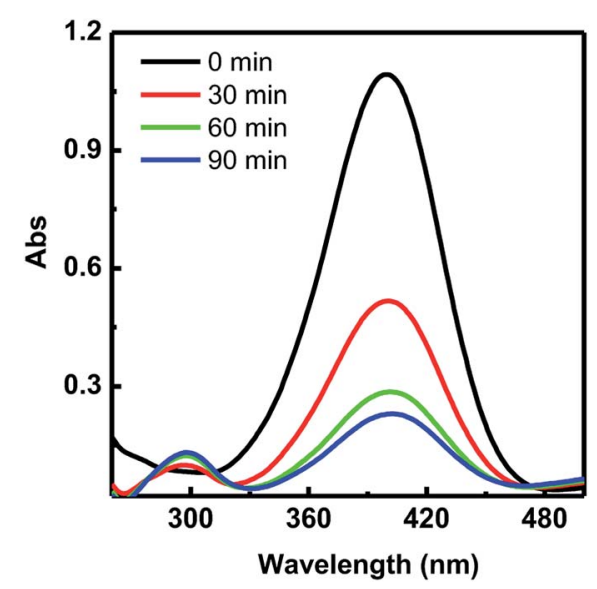

Fig. 2 Time-dependent UV-vis absorption spectra of 4-nitrophenol reduced by $\mathrm{NaBH}_{4}$ in the presence of $\mathrm{Au} @\left[\mathrm{C}_{4} \mathrm{C}_{16} \mathrm{Im}\right] \mathrm{Br}$ catalyst. compared with nitrophenols. The apparent rate constant was calculated using eqn (1) for a first-order reaction. ${ }^{38}$

$$
\ln \left(\frac{A_{t}}{A_{0}}\right)=-k_{\text {app }} t
$$

where $A_{t}$ is the absorbance of nitro compounds at time in second (s), $k_{\text {app }}$ is the apparent rate constant.

The reaction kinetics was investigated by measuring the $k_{\text {app }}$ values for the reduction of nitrophenol. The rate of reaction was determined by measuring the decrease in the absorption intensity at $\lambda_{\max }=400 \mathrm{~nm}$ of the phenolate ion with time for the reduction of nitrophenols. $k_{\text {app }}$ was calculated from the slope obtained by plotting $\ln \left(A_{t} / A_{0}\right)$ vs. time. The $k_{\text {app }}$ values were determined for 4-nitrophenol and 2-nitrophenol and given in Table 1.

According Table 1, the $k_{\text {app }}$ value for 4-nitrophenol is $1.10 \times$ $10^{-4} \mathrm{~s}^{-1}$, which is higher than that for 2-nitrophenol $(7.73 \times$ $\left.10^{-5} \mathrm{~s}^{-1}\right)$ using the $\mathrm{Au} @\left[\mathrm{C}_{4} \mathrm{C}_{16} \mathrm{Im}\right] \mathrm{Br}$ catalyst. The difference in $k_{\text {app }}$ values is explained on the basis of the position of the hydroxyl substituent in the aromatic ring. In nitrophenols, lower $k_{\text {app }}$ value for 2-nitrophenol than that of 4-nitrophenol is achieved by merely changing the position of the hydroxyl group from 4 to 2 position. The reduction occurs by the donation of an electron from $\mathrm{NaBH}_{4}$ to the $-\mathrm{NO}_{2}$ group. The para mesomeric donation is more effective than ortho mesomeric donation. Thus, 2-nitrophenol is more stabilized due to the existence of intramolecular hydrogen bonding between the $-\mathrm{OH}$ and $-\mathrm{NO}_{2}$ groups and therefore, 2-nitrophenol is less reactive for the reduction reaction compared to 4 -nitrophenol. ${ }^{38}$

Furthermore, we determined the turnover number (TON) and the turn over frequency (TOF) of $\mathrm{Au} @\left[\mathrm{C}_{4} \mathrm{C}_{16} \mathrm{Im}\right] \mathrm{Br}$ catalyst to decide the efficiency of the catalyst. In a heterogeneous catalysis reaction, the TON of catalyst is the number of substrate molecules that can convert into products using $1 \mathrm{~g}$ of catalyst, while TOF is calculated as TON/time. The substrate and catalyst concentrations used for the reduction are $1.1 \times 10^{-4} \mathrm{M}$ and $0.02 \mathrm{~g} \mathrm{~L}^{-1}$, respectively. The TOF was found to be $3.8 \times 10^{-3}$ molecules per $\mathrm{g}$ per $\mathrm{s}$ for $\mathrm{Au} @\left[\mathrm{C}_{4} \mathrm{C}_{16} \mathrm{Im}\right] \mathrm{Br}$ catalyst using the following equation:

$$
\mathrm{TOF}=\frac{m_{i} X x}{100 \mathrm{wt}}
$$

where $m_{i}$ is the initial number of moles nitrophenol, $X$ is the conversion of nitrophenol, $x$ is the molecular weight of nitrophenol, $w$ is the mass of catalyst used in the reaction ( $\mathrm{g}$ ), and $t$ is the reaction time $(\mathrm{h})$.

We also tested the catalytic activity after recycling the Au@ $\left[\mathrm{C}_{4} \mathrm{C}_{16} \mathrm{Im}\right] \mathrm{Br}$ catalyst, and it was observed to be easily recyclable and reusable. The $\mathrm{Au} @\left[\mathrm{C}_{4} \mathrm{C}_{16} \mathrm{Im}\right] \mathrm{Br}$ catalyst was recycled from

Table 1 The $k_{\text {app }}$ values for the reduction of nitrophenols in the presence of Au@ $\left[\mathrm{C}_{4} \mathrm{C}_{16} \mathrm{~lm}\right] \mathrm{Br}$ as catalyst at $298.15 \mathrm{~K}$

\begin{tabular}{lll}
\hline S. No. & Nitrophenols & $k_{\text {app }}\left(\mathrm{s}^{-1}\right)$ \\
\hline 1 & 4-Nitrophenol & $1.10 \times 10^{-4}$ \\
2 & 2-Nitrophenol & $7.73 \times 10^{-5}$
\end{tabular}


the reaction mixture by centrifugation. The catalytic activity of the recycled $\mathrm{Au} @\left[\mathrm{C}_{4} \mathrm{C}_{16} \mathrm{Im}\right] \mathrm{Br}$ catalyst was examined on the basis of $k_{\text {app }}$ values for the reduction of 4-nitrophenol. The concentration of the catalyst was $20 \mathrm{ppm}$. After recycling, the $k_{\text {app }}$ value was found to be $2.75 \times 10^{-5} \mathrm{~s}^{-1}$, which was noted to be lower than that of the pure catalyst. The lower $k_{\text {app }}$ value for the $\mathrm{Au} @\left[\mathrm{C}_{4} \mathrm{C}_{16} \mathrm{Im}\right] \mathrm{Br}$ catalyst may be due to loss of a certain amount of catalyst after the first catalytic cycle by the centrifugation and washing processes. We recorded TEM images of $\mathrm{Au} @\left[\mathrm{C}_{4} \mathrm{C}_{16} \mathrm{Im}\right] \mathrm{Br}$ after the first cycle, as shown in Fig. 3. The shape and size of AuNPs are not affected, which indicates that the AuNPs are stable enough to demonstrate catalytic activity. Thus, the decrease in $k_{\text {app }}$ value after the first use is due to the loss in amount of catalyst during recycling.

\subsection{Reaction mechanism}

The Langmuir-Hinshelwood (L-H) mechanism has been proposed by Wunder et al. for investigating kinetically controlled surface catalytic reduction reactions of 4-nitrophenol by $\mathrm{Au} / \mathrm{Pt}$ nanostructures immobilized with spherical polyelectrolyte brushes. ${ }^{35}$ According to this mechanism, the metallic nanostructure provides a surface for the catalytic reduction process to take place. ${ }^{20,39}$ The $\mathrm{BH}_{4}{ }^{-}$ions adsorb on the surface of AuNPs and transfer hydrogen species to the surface of the AuNPs. At the same time, 4-nitrophenol also adsorbs on the surface and is reduced to 4-aminophenol by the $\mathrm{BH}_{4}{ }^{-}$ions. Finally, 4-aminophenol detaches to free the surface of the NPs for the next catalytic cycle to begin. The catalytic reduction of the nitrophenols with $\mathrm{Au} @\left[\mathrm{C}_{4} \mathrm{C}_{16} \mathrm{Im}\right] \mathrm{Br}$ is a heterogeneous catalytic reduction reaction. The heterogeneous catalytic reduction reaction can take place either by the $\mathrm{L}-\mathrm{H}$ or the $\mathrm{E}-\mathrm{R}$ (Eley-Rideal mechanism). In the case of the $\mathrm{E}-\mathrm{R}$ mechanism, only one of the reactant molecules is adsorbed on the surface of the catalyst and reacts with the other reactant molecules. In the case of the $\mathrm{L}-\mathrm{H}$ mechanism, both substrate molecules, nitrophenol and $\mathrm{BH}_{4}{ }^{-}$, get adsorbed on the surface of the catalyst and then, the reaction is occurs. A reaction mechanism for the reduction of 4-nitrophenol can be investigated in two ways: (1) determination of $k_{\text {app }}$ values with different concentration of 4nitrophenol and (2) determination of $k_{\text {app }}$ values with different

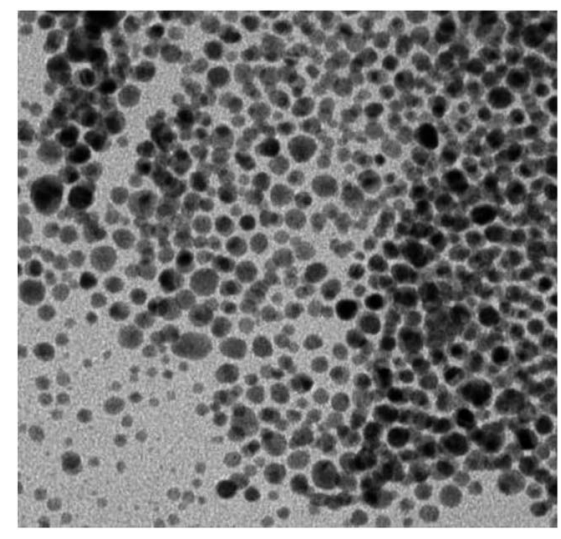

Fig. 3 TEM image of Au@ $\left[C_{4} C_{16} I m\right] B r$ after first recycle. concentrations of $\mathrm{NaBH}_{4}$. In the $\mathrm{L}-\mathrm{H}$ mechanism, the $k_{\text {app }}$ value decreases with the concentration of 4-nitrophenol, while it increases with the concentration of $\mathrm{NaBH}_{4}$. However, in case of the E-R mechanism, the $k_{\text {app }}$ value increases with the concentration of 4-nitrophenol. We know that the reduction of 4nitrophenol is a first-order reaction with respect to 4-nitrophenol. The $k_{\text {app }}$ values of the catalytic reduction reaction are proportional to the surface area of the materials. The kinetic rate constant can be determined as $^{\mathbf{4 0 - 4 2}}$

$$
\frac{\mathrm{d} c_{\mathrm{NP}}}{\mathrm{d} t}=k c_{\mathrm{NP}}=k_{1} S c_{\mathrm{NP}}
$$

In terms of the Langmuir-Freundlich isotherm

$$
\theta_{i}=\frac{\left(k_{i} c_{i}\right)^{n_{i}}}{1+\sum_{j=1}^{N}\left(K_{j} c_{j}\right)}
$$

where $\theta_{i}$ is the surface coverage of substrate $i, k_{i}$ the adsorption constant of the respective components, $c_{i}$ the concentration and $n$ the heterogeneity of the surface materials. The rearrangement of eqn (4) gives an eqn (5), which can be used to model the catalytic activity.

$$
-\frac{\mathrm{d} c_{\mathrm{NP}}}{\mathrm{d} t}=\frac{k S\left(K_{\mathrm{NP}} c_{\mathrm{NP}}\right)^{n}\left(K_{\mathrm{BH}_{4}} c_{\mathrm{BH}_{4}}\right)^{m}}{\left(1+\left(K_{\mathrm{NP}} c_{\mathrm{NP}}\right)^{n}+\left(K_{\mathrm{BH}_{4}} c_{\mathrm{BH}_{4}}\right)^{m}\right)^{2}}=k_{\mathrm{app}} c_{\mathrm{NP}}
$$

Thus, $k_{\text {app }}$ is given by

$$
\theta_{i}=\frac{k S K_{\mathrm{NP}}^{n} c_{\mathrm{NP}}^{n-1}\left(K_{\mathrm{BH}_{4}} c_{\mathrm{BH}_{4}}\right)^{m}}{\left(1+\left(K_{\mathrm{NP}} c_{\mathrm{NP}}\right)^{n}+\left(K_{\mathrm{BH}_{4}} c_{\mathrm{BH}_{4}}\right)^{m}\right)^{2}}
$$

where $k$ is the molar rate constant per square meter of catalyst, $K_{\mathrm{NP}}$ is the adsorption coefficient of the nitrocompounds, and $K_{\mathrm{BH}_{4}}$ is the adsorption coefficient of $\mathrm{BH}_{4}{ }^{-}$. The plot of the $k_{\text {app }}$ values versus the concentration of 4-nitrophenol at a fixed concentration of $\mathrm{NaBH}_{4}$ of $1 \times 10^{-3} \mathrm{M}$ in the presence of Au@ $\left[\mathrm{C}_{4} \mathrm{C}_{16} \mathrm{Im}\right] \mathrm{Br}$ at $298.15 \mathrm{~K}$ are given in Fig. 4 . The $k_{\text {app }}$ values

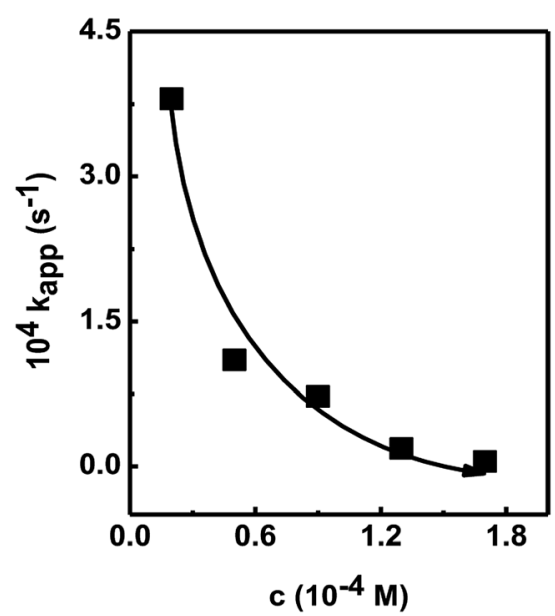

Fig. 4 Plot of $k_{\text {app }} v s$. conc. of 4-nitrophenol in the presence of AuC $\left[\mathrm{C}_{4} \mathrm{C}_{16} \mathrm{Im}\right] \mathrm{Br}$ catalyst. Lines drawn to guide the reader's eye. 


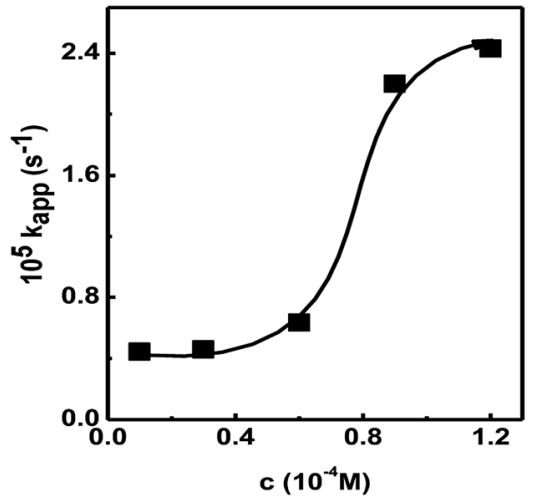

Fig. 5 Plot of $k_{\text {app }}$ vs. conc. $\mathrm{NaBH}_{4}$ in the presence of Au $\mathrm{a}\left[\mathrm{C}_{4} \mathrm{C}_{16} \mathrm{Im}\right] \mathrm{Br}$ catalyst. Lines drawn to guide the reader's eye.

Table 2 Temperature dependent $k_{\text {app }}$ values for the reduction of 4nitrophenol and 2-nitrophenol

\begin{tabular}{llll}
\hline S. No. & $\begin{array}{l}\text { Temperature } \\
(\mathrm{K})\end{array}$ & $\begin{array}{l}\text { 4-Nitrophenol, } \\
k_{\text {app }}\left(\mathrm{s}^{-1}\right)\left(10^{-4}\right)\end{array}$ & $\begin{array}{l}\text { 2-Nitrophenol, } \\
k_{\text {app }}\left(\mathrm{s}^{-1}\right)\left(10^{-4}\right)\end{array}$ \\
\hline 1 & 293.15 & 1.03 & 0.25 \\
2 & 298.15 & 1.10 & 0.77 \\
3 & 303.15 & 2.14 & 1.74 \\
4 & 310.15 & 9.84 & 5.14 \\
5 & 318.15 & 17.8 & 6.04 \\
\hline
\end{tabular}

decreased with increase in concentration of 4-nitrophenol. Similarly, the plot of $k_{\text {app }}$ values versus the concentration of $\mathrm{NaBH}_{4}$ with a fixed concentration of 4-nitrophenol of $1.1 \times$ $10^{-4} \mathrm{M}$ in the presence of $\mathrm{Au} @\left[\mathrm{C}_{4} \mathrm{C}_{16} \mathrm{Im}\right] \mathrm{Br}$ at $298.15 \mathrm{~K}$ is given in Fig. 5. The $k_{\text {app }}$ values increased with increase in the concentration of $\mathrm{NaBH}_{4}$. Thus, the nonlinear variation of the $k_{\text {app }}$ values with respect to the concentration of 4-nitrophenol and $\mathrm{NaBH}_{4}$ shows that the reduction of 4-nitrophenol follows the $\mathrm{L}-\mathrm{H}$ mechanism. The number of molecules adsorbed at the surface of the $\mathrm{Au} @\left[\mathrm{C}_{4} \mathrm{C}_{16} \mathrm{Im}\right] \mathrm{Br}$ nanocatalyst increases with the increase in the concentration of 4-nitrophenol and hence, the surface becomes saturated by 4-nitrophenol molecules.

This leads to a decrease in concentration of $\mathrm{BH}_{4}{ }^{-}$ions approaching the surface of the $\mathrm{Au} @\left[\mathrm{C}_{4} \mathrm{C}_{16} \mathrm{Im}\right] \mathrm{Br}$ catalyst, hence lowering the rate of hydrogen transfer from $\mathrm{BH}_{4}{ }^{-}$ion to the 4nitrophenol molecule. This confirms that the $\mathrm{Au} @\left[\mathrm{C}_{4} \mathrm{C}_{16} \mathrm{Im}\right] \mathrm{Br}$ catalyzed reduction of nitrophenol occurs according to the $\mathrm{L}-\mathrm{H}$ mechanism.

\subsection{Thermodynamics study of kinetics of the reduction of nitrophenol}

We investigated the temperature-dependent reduction reaction of 4-nitrophenol and 2-nitrophenol catalyzed by $\mathrm{Au} @\left[\mathrm{C}_{4} \mathrm{C}_{16} \mathrm{Im}\right]$ $\mathrm{Br}$ at five different temperatures. The $k_{\text {app }}$ values for the reduction of 4-nitrophenol and 2-nitrophenol increased with the increase in temperature, as given in Table 2, because of an increase in the diffusion of reactant molecules.

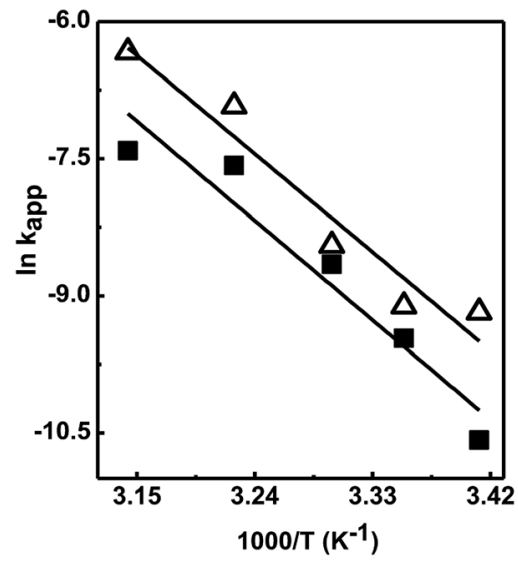

Fig. 6 The Arrhenius plots of $\ln k_{\text {app }} v s .1 / T$ for the reduction reaction of 4-nitrophenol $(\Delta)$ and 2-nitrophenol $(\boldsymbol{\square})$ with $\mathrm{NaBH}_{4}$ at different temperature.

The activation energies $\left(E_{\mathrm{a}}\right)$ for the reduction reaction of 4nitrophenol and 2-nitrophenol were determined from the Arrhenius eqn (7): ${ }^{43-45}$

$$
\ln k=\ln A-\frac{E_{\mathrm{a}}}{R T}
$$

where $E_{\mathrm{a}}$, is activation energy, $A$ is Arrhenius factor, $T$ is temperature and $R$ is the ideal gas constant. The values of $E_{\mathrm{a}}$ were determined from the slope of the plot of $\ln k v s$. $1 / T$, as shown in Fig. 6 and Table 3.

The activation parameters for the catalytic reduction of nitrophenol using AuNPs are summarized in Table 3. The $E_{\mathrm{a}}$ values for the reduction of nitrocompounds, mainly for 4nitrophenol catalyzed by different metals and metal NPs, have been determined by many research groups. For example, the $E_{\mathrm{a}}$ values for the reduction of 4-nitrophenol using dendrimerencapsulated palladium NPs and for a palladium nanocage structure are $30 \mathrm{~kJ} \mathrm{~mol}^{-1}$ and $109 \mathrm{~kJ} \mathrm{~mol}^{-1}$, respectively. ${ }^{24}$

In this study, the activation energies $E_{\mathrm{a}}$ for 4-nitrophenol and 2-nitrophenol are 99.40 and $100.59 \mathrm{~kJ} \mathrm{~mol}^{-1}$, respectively which are in good agreement with literature values and confirms that the reaction follows the $\mathrm{L}-\mathrm{H}$ mechanism.

Thermodynamic parameters such as activation enthalpy $\left(\Delta H^{\#}\right)$ and activation entropy $\left(\Delta S^{\#}\right)$ for the reduction of 4-nitrophenol and 2-nitrophenol were determined using the Eyring equation (eqn (8)). ${ }^{38}$

$$
\begin{gathered}
\ln \frac{k_{\text {app }}}{T}=\ln \left(\frac{k_{\mathrm{B}}}{h}\right)+\frac{\Delta S^{\#}}{R}-\frac{\Delta H^{\#}}{R T} \\
\Delta G=\Delta H-T \Delta S
\end{gathered}
$$

where $k_{\text {app }}$ is the rate constant $\left(\mathrm{s}^{-1}\right), R$ is the universal gas constant, $T$ is temperature $(\mathrm{K}), h$ is the Plank constant, $k_{\mathrm{B}}$ is the Boltzmann constant, and $\Delta G$ is the Gibb's free energy. The thermodynamic parameters $\Delta H^{\#}$ and $\Delta S^{\#}$ were obtained from Fig. S2 $\uparrow$ and represented in Table 3.

The values of $k_{\text {app }}$ were 1.10 and $0.77 \mathrm{~s}^{-1}$, corresponding to 4 nitrophenol and 2-nitrophenol, respectively. Moreover, the $E_{\mathrm{a}}$ 
Table 3 Thermodynamic parameters $\Delta H^{\#}, \Delta S^{\#}, \Delta G^{\#}$ and $E_{a}$ for the reduction of nitrophenols using Au@ $\left[C_{4} C_{16} I m\right] B r$ as catalyst

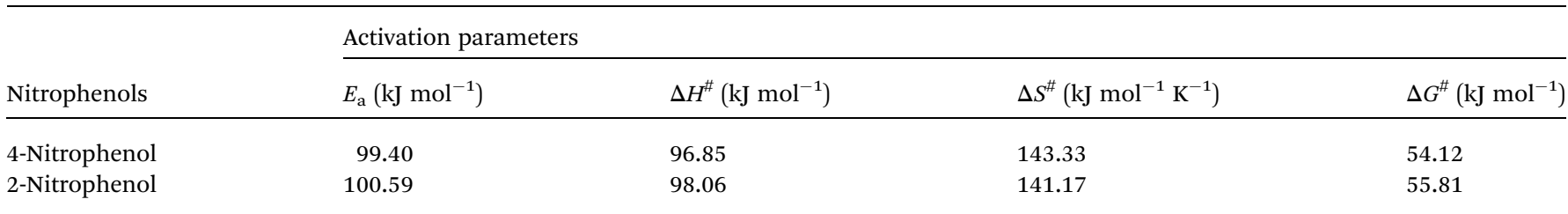

value is higher for 2-nitrophenol compared with that of 4nitrophenol, which reflects the rate constant $\left(k_{\text {app }}\right)$ data. Similar trend is observed for other activation parameters $\Delta H^{\#}$ and $\Delta S^{\#}$. To proceed with the reduction reaction, for 2-nitrophenol to adsorbs on the catalyst surface, it needs to cross a higher energy barrier compared with that for 4-nitrophenol. Thus, the reactivity of nitrophenol is dependent on the substitution position of the hydroxyl group, which forms the intramolecular hydrogen bond with the nitro group; this is also confirmed from the kinetic data. The insignificant difference in reactivity of the nitrophenols is observed due to the different ability of the nitrophenols to form intramolecular hydrogen bonds. Hence, the AuNPs in the presence of $\left[\mathrm{C}_{4} \mathrm{C}_{16} \mathrm{Im}\right] \mathrm{Br}$ show excellent catalytic activity. The detailed mechanism has been explained in the earlier section.

\section{Conclusions}

In conclusion, we synthesized and characterized ionic liquidstabilized $\mathrm{Au} @\left[\mathrm{C}_{4} \mathrm{C}_{16} \mathrm{Im}\right] \mathrm{Br}$ in water with an average size of $10 \mathrm{~nm}$. The catalytic activity of $\mathrm{Au} @\left[\mathrm{C}_{4} \mathrm{C}_{16} \mathrm{Im}\right] \mathrm{Br}$ for the reduction of nitrophenols in the presence of $\mathrm{NaBH}_{4}$ was examined. (1) The kinetics of reduction of nitrophenols was investigated using $\mathrm{Au} @\left[\mathrm{C}_{4} \mathrm{C}_{16} \mathrm{Im}\right] \mathrm{Br}$ as a catalyst, and excellent catalytic activity with good recyclability was observed over multiple cycles of reduction of nitrophenols. (2) The $k_{\text {app }}$ values for the reduction of 4-nitrophenol is higher than that for the reduction of 2nitrophenol because of the intramolecular hydrogen bonding present in 2-nitrophenol. (3) The $\mathrm{L}-\mathrm{H}$ reaction mechanism for the reduction of nitrophenols by $\mathrm{Au} @\left[\mathrm{C}_{4} \mathrm{C}_{16} \mathrm{Im}\right] \mathrm{Br}$ was confirmed on the basis of the $k_{\text {app }}$ values and thermodynamic parameters. (4) Thermodynamic parameters such as $\Delta H^{\#}, \Delta S^{\#}$, $\Delta \mathrm{G}^{\#}$ and $E_{\mathrm{a}}$ for the reduction of nitrophenol were determined by temperature-dependent kinetic studies using the Arrhenius and Eyring equations. The results obtained in this investigation are useful for the fabrication of highly efficient metal nanocatalysts using ionic liquids as stabilizing agents for the reduction of nitrophenols.

\section{Conflicts of interest}

There are no conflicts to declare.

\section{Acknowledgements}

NDK acknowledges SERB, New Delhi for Young Scientist Research Grant (YSS/2015/001229). The authors appreciate the anonymous reviewers for offering constructive evaluation of the study. S. R. T. thanks CSIR, New Delhi, for awarding him a Senior Research Fellowship and Dr Anil Kumar NCL Pune thanked for Scientific and Constructive suggestions and experimental facility.

\section{References}

1 B. Hinnemann, P. G. Moses, J. Bonde, K. P. Jørgensen, J. H. Nielsen, S. Horch, I. Chorkendorff and J. K. Nørskov, J. Am. Chem. Soc., 2005, 127, 5308-5309.

2 M. Kohantorabi and M. R. Gholami, Ind. Eng. Chem. Res., 2017, 56, 1159-1167.

3 Z. Wang, R. Su, D. Wang, J. Shi, J. Wang, Y. Pu and J. F. Chen, Ind. Eng. Chem. Res., 2017, 56, 13610-13617.

4 M. H. Rashid and T. K. Mandal, J. Phys. Chem. C, 2007, 111, 16750-16760.

5 A. Virel, L. Saa and V. Pavlov, Anal. Chem., 2009, 81, 268-272.

6 M. Breton, G. Prével, J. F. Audibert, R. Pansu, P. Tauc, B. Le Pioufle, O. Français, J. Fresnais, J. F. Berret and E. Ishow, Phys. Chem. Chem. Phys., 2011, 13, 13268-13276.

7 J. Li, Z. Shen, X. Ma, W. Ren, L. Xiang, A. Gong, T. Xia, J. Guo and A. Wu, ACS Appl. Mater. Interfaces, 2015, 7, 5574-5582.

8 S. M. Ansar and C. L. Kitchens, ACS Catal., 2016, 6, 55535560.

9 M. H. Rashid, R. R. Bhattacharjee, A. Kotal and T. K. Mandal, Langmuir, 2006, 22, 7141-7143.

10 X. Bai, Y. Gao, H. Liu and L. Zheng, J. Phys. Chem. C, 2009, 113, 17730-17736.

11 B. P. Binks, A. Desforges and D. G. Duff, Langmuir, 2007, 23, 1098-1106.

12 J. Huang and Y. Wang, J. Phys. Chem. B, 2007, 111, 77357741.

13 C. M. Phan and H. M. Nguyen, J. Phys. Chem. A, 2017, 121, 3213-3219.

14 X. Bai, H. Ma, X. Li, B. Dong and L. Zheng, Langmuir, 2010, 26, 14970-14974.

15 J. T. Lu, J. C. Lin, M. C. Lin, N. D. Khupse and I. J. B. Lin, Langmuir, 2014, 30, 10440-10448.

$16 \mathrm{P}$. Wassercheid and T. Welton, Ionic liquids in synthesis, Wiley-VCH Verlag GmbH and Co. GaA, 2008.

17 S. Thawarkar, B. Thombare and N. D. Khupse, New J. Chem., 2017, 41, 12989-12995.

18 Y. Yang, Y. Ren, C. Sun and S. Hao, Green Chem., 2014, 16, 2273.

19 S. A. Lawrence, Amines: Synthesis, Properties and Applications, Cambridge University Press, New York, 2004.

20 Y. Zhang, Z. Cui, L. Li, L. Guo and S. Yang, Phys. Chem. Chem. Phys., 2015, 17, 14656-14661. 
21 (a) P. Deka, R. C. Deka and P. Bharali, New J. Chem., 2014, 38, 1789; (b) H. Yang, S. Li, X. Zhang, X. Wang and J. Ma, J. Mater. Chem. A, 2014, 2, 12060-12067.

22 T. Aditya, A. Pal and T. Pal, Chem. Commun., 2015, 51, 94109431.

23 k. Layek, M. L. Kantam, M. Shirai, D. Nishio-Hamane, T. Sasaki and H. Maheswaran, Green Chem., 2012, 14, 3164.

24 M. A. Mahmoud, F. Saira and M. A. El-Sayed, Nano Lett., 2010, 10, 3764-3769.

25 C. Y. Wang, C. F. Fu, Y. H. Liu, S. M. Peng and S. T. Liu, Inorg. Chem., 2007, 46, 5779-5786.

26 Z. D. Pozun, S. E. Rodenbusch, E. Keller, K. Tran, W. Tang, K. J. Stevenson and G. J. Henkelman, J. Phys. Chem. C, 2013, 117, 7598-7604.

27 B. Baruah, G. J. Gabriel, M. J. Akbashev and M. E. Booher, Langmuir, 2013, 29, 4225-4234.

28 N. Pradhan, A. Pal and T. Pal, Langmuir, 2001, 17, 1800-1802.

29 N. Bingwa, R. Patala, J. H. Noh, M. J. Ndolomingo, S. Tetyana, S. Bewana and R. Meijboom, Langmuir, 2017, 33, 7086-7095.

30 F. Lin and R. Doong, J. Phys. Chem. C, 2017, 121, 7844-7853.

31 A. Shivhare, S. J. Ambrose, H. Zhang, R. W. Purves and R. W. Scott, Chem. Commun., 2013, 49, 276-278.

32 Y. Khalavka, J. Becker and C. Sönnichsen, J. Am. Chem. Soc., 2009, 131, 1871-1875.

33 H. Zhang, X. Li and G. Chen, J. Mater. Chem., 2009, 19, 8223.
34 M. Hajfathalian, K. D. Gilroy, A. Yaghoubzade, A. Sundar, T. Tan, R. A. Hughes and S. Neretina, J. Phys. Chem. C, 2015, 119, 17308-17315.

35 S. Wunder, F. Polzer, Y. Lu, Y. Mei and M. J. Ballauff, J. Phys. Chem. C, 2010, 114, 8814-8820.

36 S. Gu, S. Wunder, Y. Lu, M. Ballauff, R. Fenger, K. Rademann, B. Jaquet and A. Zaccone, J. Phys. Chem. C, 2014, 118, 18618-18625.

37 H. S. Schrekker, M. A. Gelesky, M. P. Stracke, C. M. L. Schrekker, G. Machado, S. R. Teixeira, J. C. Rubim and J. Dupont, J. Colloid Interface Sci., 2007, 316, 189-195.

38 S. R. Thawarkar, N. D. Khupse and A. Kumar, ChemistrySelect, 2017, 2, 6833-6843.

39 N. C. Antonels and R. Meijboom, Langmuir, 2013, 29, 1343313442.

40 M. Li and G. Chen, Nanoscale, 2013, 5, 11919.

41 L. Glasser, J. Chem. Educ., 1979, 56, 22.

42 N. Bingwa and R. Meijboom, J. Phys. Chem. C, 2014, 118, 19849-19858.

43 S. Saha, A. Pal, S. Kundu, S. Basu and T. Pal, Langmuir, 2010, 26, 2885-2893.

44 J. Tang, Z. Shi, R. M. Berry and K. C. Tam, Ind. Eng. Chem. Res., 2015, 54, 3299-3308.

45 T. Zhou, T. Liu, Z. Zhang, G. Zhang, F. Wang, X. Wang, S. Liu, H. Zhang, S. Wang and J. Ma, J. Solid State Chem., 2018, 1117. 